\title{
Shape and size of jatropha beans (Jatropha curcas L.) during drying at different temperatures ${ }^{1}$
}

\author{
Valdiney Cambuy Siqueira², Osvaldo Resende ${ }^{3}$, Tarcísio Honório Chaves ${ }^{4}$
}

\begin{abstract}
This study was carried out to study the physical properties of the jatropha beans over the drying under six air conditions, based on measurements of roundness, sphericity, volume, superficial area, projected area and surface/ volume ratio. Jatropha beans with moisture content around 0.61 (decimal d.b.) were subjected to thin-layer drying in oven with forced-air circulation under six temperature conditions $\left(36,45,60,75,90\right.$ and $\left.105^{\circ} \mathrm{C}\right)$ and relative humidity of $31.7 ; 19.6 ; 9.4 ; 4.8 ; 2.6$ and $1.5 \%$ respectively, until reaching the moisture content of $0.11 \pm 0.006$ (decimal d. b.). The results showed that the necessary time for jatropha beans to reach the moisture content of $0.11 \pm 0.006$ (decimal d.b.) were $1.5 ; 2.25 ; 3.0 ; 4.75 ; 6.75$ and $12.0 \mathrm{~h}$ for the drying temperatures of $105,90,75,60,45$ and $36^{\circ} \mathrm{C}$, respectively; and the reduction in the moisture content as well as the drying conditions promoted changes in the shape and reduced the size of the jatropha beans.
\end{abstract}

Key words: physical properties, moisture content, roundness, sphericity.

\section{RESUMO}

\section{Forma e tamanho dos grãos de pinhão-manso (Jatropha curcas $L$.) durante a secagem em diferentes temperaturas}

Este trabalho teve por objetivo estudar as propriedades físicas dos de pinhão-manso durante a secagem em seis condições do ar, por meio de circularidade, esfericidade, volume, área superficial, área projetada e relação superfícievolume. Os grãos de pinhão-manso com teor de água em torno de 0,61 (decimal b.s.)foram submetidos à secagem em camada fina, em estufa com circulação forçada de ar em seis condições de temperatura $\left(36,45,60,75,90\right.$ e $\left.105^{\circ} \mathrm{C}\right) \mathrm{e}$ umidade relativa de 31,$7 ; 19,6 ; 9,4 ; 4,8 ; 2,6 ;$ e 1,5\%, respectivamente, até atingir o teor de água de $0,11 \pm 0,006$ (decimal b.s.). Concluiu-se que: os tempos necessários para os de pinhão-manso alcançarem o teor de água de $0,11 \pm 0,006$ (decimal b.s.) foram 1,$5 ; 2,25 ; 3,0 ; 4,75 ; 6,75 ; \mathrm{e} 12,0 \mathrm{~h}$ para as temperaturas de secagem de $105,90,75,60,45 \mathrm{e} 36^{\circ} \mathrm{C}$, respectivamente. A redução do teor de água e as condições de secagem causaram alterações na forma e reduziram o tamanho dos grãos de pinhão.

Palavras-chave: propriedades físicas, teor de água, circularidade, esfericidade.

Received: 27/04/2012; Accepted: 08/07/2013.

'Part of the Master's dissertation of the first author.

2 Agronomist Engineer, Master of Science. Faculdade de Ciências Agrárias, Universidade Federal da Grande Dourados, Rodovia Dourados-Itaum, km 12, Caixa Postal 533, CEP: 79804-970, Dourados, Mato Grosso do Sul, Brasil.vcambuy@yahoo.com (corresponding author).

${ }^{3}$ Agricultural Engineer, Doctor of Science. Instituto Federal Goiano, Campus Rio Verde, Rodovia Sul Goiana, Km 01, Zona Rural, 75901-970, Rio Verde, Goiás, Brasil. osvresende@yahoo.com.br

${ }^{4}$ Undergraduate in Agronomy. Instituto Federal Goiano, Campus Rio Verde, Rodovia Sul Goiana, Km 01, Zona Rural, 75901-970, Rio Verde, Goiás, Brasil. tarcisiohonoriochaves@ymail.com 


\section{INTRODUCTION}

In the last years, research has been searching for alternative fuels to crude oil such as biodiesel, since it is a renewable source and it promotes lower impact on the environment. In addition, it is well-known that the sources of fossil fuels are limited and their future exhaustion has been forecasted (Siqueira, 2011).

Jatropha beans (Jatropha curcas L.) are among the plants with high potential for biodiesel production. According to Santos et al. (2009), the oil produced from jatropha beans has all necessary qualities to be transformed into diesel oil. The authors also emphasize the wide geographical distribution of the plant, since jatropha can adapt to very variable edaphoclimatic conditions due to its rusticity, resistance to lengthy droughts and to pests and diseases. However, such as in any other plant species, the genetic material and the technological level adopted in the crop are extremely important for a satisfactory yield.

Most of the jatropha cultivation is still accomplished in small farms in which the harvest, drying and storage processes are accomplished with reduced technological inputs. With the arrival of the biodiesel, however, new technologies should be adopted to attend the needs of the wide-scale production (Santos et al., 2009). Thus, the knowledge on the behavior of the physical properties of jatropha beans are important for development of the machinery used at the harvest and post-harvest stages.

Among the post-harvest stages, the drying is highly important because it is directly related to final quality of the product. Drying aims to the reduction in the moisture content to safe levels, while hindering and/or inhibiting the growth of the microorganisms, as reducing both the proliferation of insects and the metabolic activity of the beans. During drying, besides changes in their mass, the beans also undergo changes in their shape and size. Considering that the extraction of the jatropha oil is carried out after drying, the knowledge on the bean physical behavior along the drying process is crucial (Siqueira, 2011; Siqueira et al., 2012).

According to Resende et al. (2005), the reduced moisture content in beans besides provoking their shrinkage also directly affects their physical properties during the drying process. The physical properties of the physic nut fruit are essential for designing the equipment to be used in harvest, drying, cleaning, classification, peeling and storage (Pradhan et al., 2009). According to Silva (2008), the knowledge on the physical properties of the agricultural products is also extremely important for adaptation of the available equipment in order to obtain higher return in the processing operations.
These data are used in dimensioning both size and shape of the beans sieves in equipment destined to the separation and classification (Silva, 2008). According to Sirisomboon et al. (2007), the size (superficial area, projected area and volume) and shape (roundness, sphericity) of fruits, nuts and seeds are important for the peeling process of these products. These data could be used to determine the inferior limit of the transporter size, such as matting, chain bucket and helical transporter. The superficial area and the surface/volume ratio affect the resistance to passage of the air flow through the material layer, thus information on these variables is important for the best description of the drying process.

Taking into account the advantages of the biodiesel production, the importance of the drying process and its influence on the bean physical properties, the main objectives of the present study were: to evaluate both shape and size of jatropha beans, based on its roundness, sphericity, volume, superficial area, projected area and the surface/volume ratio along the drying process under different air conditions.

\section{MATERIAL AND METHODS}

The experiment was carried out at the IF Post-Harvest Laboratory (Instituto Federal de Educação, Ciência e Tecnologia Goiano - Campus Rio Verde - GO, Brazil). Jatropha beans with moisture content of 0.61 (decimal d.b.) were used in the experiment. The beans were subjected to drying in oven with forced air ventilation at six temperatures: $36,45,60,75,90$ and $105^{\circ} \mathrm{C}$ and relative humidity of $31.7 ; 19.6 ; 9.4 ; 4.8 ; 2.6$ and $1.5 \%$, respectively, until reaching the moisture content $(\mathrm{MC})$ of $0.11 \pm 0.006$ (decimal d.b.) determined in oven at $105 \pm 1{ }^{\circ} \mathrm{C}$ during 24 h, with three replicates (Brasil, 2009).

For the trial it was used 20 jatropha beans samples individualized in labelled aluminum perforated capsules. At each 15 minutes interval, the beans were measured at three positions (length, width and thickness), by using a digital caliper with $0.01 \mathrm{~mm}$ resolution. The reduction in the moisture content was determined by weighing three trays with $300 \mathrm{~g}$ of beans kept under the same drying conditions to which the initial 20 beans were subjected.

The shape of the jatropha beans considered as spheroid was obtained through sphericity and roundness measures according to the characteristic dimensions expressed by the orthogonal axes (Figure 1).

The sphericity $\left(\mathrm{E}_{\mathrm{s}}\right)$ was determined according to the following equation (Mohsenin, 1986):

$\mathrm{E}_{\mathrm{S}}=\left[{\frac{(\mathrm{a} \cdot \mathrm{b} . \mathrm{c})^{1 / 3}}{\mathrm{a}}}^{1 / 3}\right] \cdot 100$ 
where,

a: longest axis of the bean, mm; b: medium axis of the bean, $\mathrm{mm}$; $\mathrm{c}$ : shortest axis of the bean, $\mathrm{mm}$.

The roundness $(\mathrm{C})$ of the jatropha beans at natural flat position was obtained by using the equation proposed by Mohsenin (1986), as follows:

$\mathrm{C}=\frac{\mathrm{b}}{\mathrm{a}} \cdot 100$

The superficial area (S), in $\mathrm{mm}^{2}$, was calculated by analogy to a sphere with the same average geometric diameter, by using the following equation (TundeAkinntunde \& Akintunde, 2004):

$\mathrm{S}=\pi \cdot \mathrm{D}_{\mathrm{g}}$

According to Mohsenin (1986):

$\mathrm{D}_{\mathrm{g}}=(\mathrm{a} \cdot \mathrm{b} \cdot \mathrm{c})^{1 / 3}$

were:

$\mathrm{D}_{\mathrm{g}}$ : average geometric diameter, $\mathrm{mm}$.

The projected area $\left(\mathrm{A}_{\mathrm{p}}\right)$, in $\mathrm{mm}^{2}$, of the jatropha beans were determined by using the following equation (Goneli et al., 2008):

$\mathrm{A}_{\mathrm{p}}=\frac{\pi \cdot \mathrm{a} \cdot \mathrm{b}}{4}$

Each bean volume $\left(\mathrm{V}_{\mathrm{g}}\right)$ in mm was obtained along the drying process, according to the equation proposed by Mohsenin (1986):

$\mathrm{V}_{\mathrm{g}}=\frac{\pi \cdot \mathrm{a} \cdot \mathrm{b} \cdot \mathrm{c}}{6}$

The surface-volume relationship (SV) was calculated by the following equation:

$\mathrm{SV}=\frac{\mathrm{S}}{\mathrm{V}_{\mathrm{g}}}$

The data were analyzed using the variance and regression analysis and the models were selected according to the determination coefficient and the significance of the equation by the F-test was considered at $1 \%$ probability level.

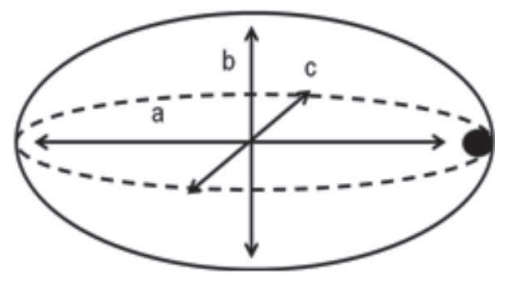

Figure 1. Schematic drawing of the jatropha beans, considered as spheroid, with their characteristic dimensions.

\section{RESULTS AND DISCUSSION}

The time necessary for the jatropha beans to reach the moisture content of $0.11 \pm 0.006$ (decimal d.b.) were 1.5; $2.25 ; 3.0 ; 4.75 ; 6.75$ and $12.0 \mathrm{~h}$ for the drying temperatures of $105,90,75,60,45$ and $36^{\circ} \mathrm{C}$, respectively (Figure 2). Thus, the increase in temperature promoted the reduction in the drying time of the jatropha beans, therefore evidencing the increase in the drying rate, which was already observed by other researchers for a number of agricultural products (Lahsasni et al., 2004; Mohapatra \& Rao, 2005; Resende et al., 2008; Sirisomboon \& Kitchaiya, 2009; Resende et al., 2010).

During the drying process, the sphericity noticeably increased and was followed by slight reduction for temperatures of $105,90,75,60$ and $45^{\circ} \mathrm{C}$ (Figure 3 ). When evaluating the sphericity of the wheat kernels during the drying process, Corrêa et al. (2006) observed a similar behavior. However, the beans subjected to drying at 36 ${ }^{\circ} \mathrm{C}$ presented reduced sphericity, probably due to low rate of the moisture removal under this drying condition.

Also the sphericity of the jatropha beans ranges between 66 and 68\% (Figure 3). Similar results were reported by Santos et al. (2009), where jatropha beans with moisture content of $8.73 \pm 0.099 \%$ (w.b.) showed $65 \%$

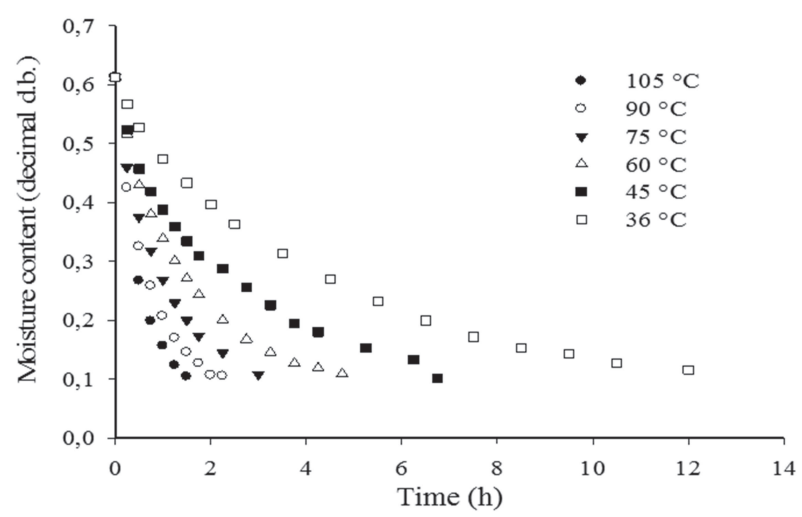

Figure 2. Moisture contents of the jatropha beans along the drying time (h) at different drying temperatures

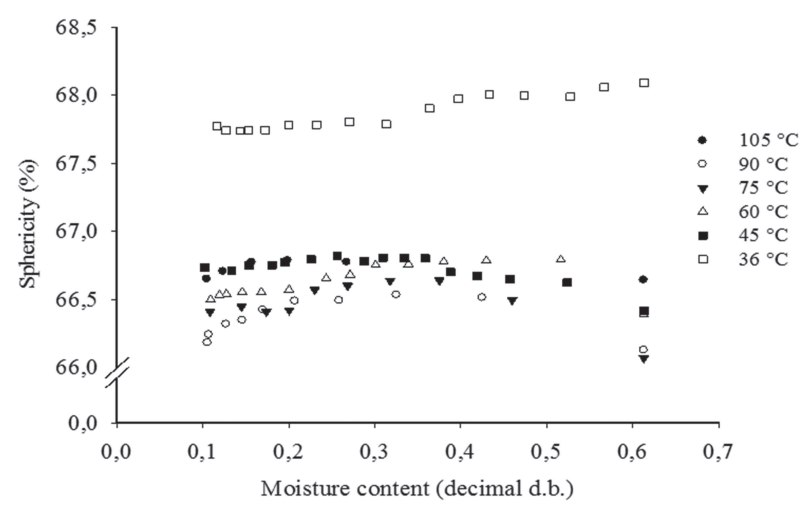

Figure 3. Sphericity of the jatropha beans as a function of the moisture content at different drying temperatures. 
sphericity, and Garnayak et al. (2008) who found the sphericity of jatropha beans to be 66 to $67 \%$ for the moisture content ranging from 4.75 to $19.57 \%$ (w.b.).

The contraction of the medium-length axis relative to the longest axis was not directly proportional along the reduction of the bean moisture content, except for $36^{\circ} \mathrm{C}$ at which a slight decrease of the roundness occurred (Figure 4). So, at drying temperatures of 105, 90, 75, 60, and 45 ${ }^{\circ} \mathrm{C}$, the contraction of the longest axis was lower relative to the medium axis. Similar results were observed by Resende et al. (2005), when studying the roundness of the red bean during drying. Since the drying of the beans at $36^{\circ} \mathrm{C}$ occurred slowly $(12 \mathrm{~h})$, this promoted a contraction proportional to the medium axis relative to the longest axis, as explaining its inverse behavior relative to other drying temperatures.

Nóbrega et al. (2001) proposed a classification for castor-oil beans relative to their shape, as a function of the ratio between length and width. According to this ratio, the beans can be considered as long when this ratio is higher than 1.2; roundish, when this ratio ranges between 0.8 and 1.2; and flattened, when this ratio is lower than 0.8 . Thus, the jatropha beans might be classified as long, since they presented the length/wideness ratio above 1.58 for all temperatures and all moisture contents under analysis.

The reduction of the moisture content from 0.61 to $0.11 \pm 0.006$ (decimal d.b.), a decrease of $111.54 ; 139.47$; $128.23 ; 137.68 ; 148.06$; and 139.98 occurred relative to initial volume, for the temperatures 105, 90, 75, 60, 45 and $36{ }^{\circ} \mathrm{C}$, respectively (Figure 5). For higher temperatures $\left(105,90\right.$, and $\left.75^{\circ} \mathrm{C}\right)$, the reduction in the volume was lower, mainly for beans subjected to drying at $105^{\circ} \mathrm{C}$. At this temperature, a high rate of moisture removal occurred, causing the hardening of the tegument, which could hamper the contraction of the beans and consequently reduce its volume at lower intensity. At lower temperatures $\left(60,45\right.$ and $\left.36^{\circ} \mathrm{C}\right)$, the reduction in the initial volume was higher, since the water was more slowly removed and the

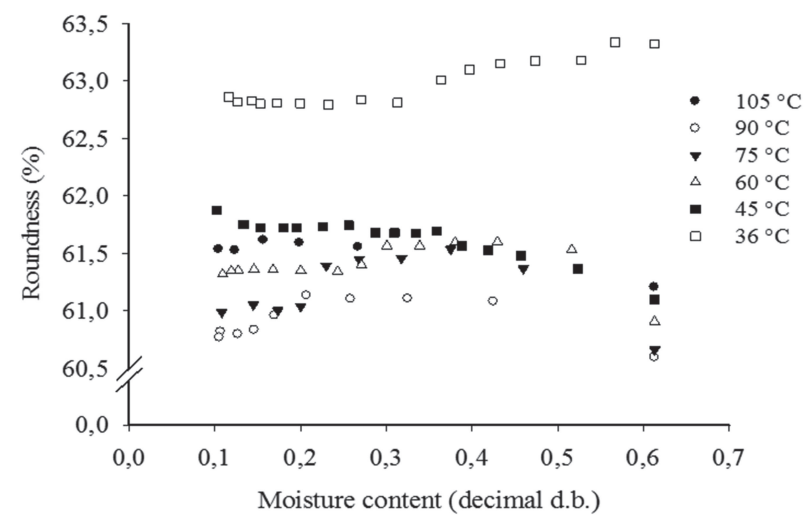

Figure 4. Roundness of the jatropha beans subjected to six drying temperatures. beans constricted the orthogonal axes according to reduction of the moisture content.

The superficial area of the jatropha beans diminished when the moisture content was reduced (Figure 6). The variation of the superficial area of the jatropha beans as a function of the drying temperature showed the same behavior of the volume. Therefore, the superficial area of the jatropha beans was affected by the drying air temperature and was directly related with both volume and content of the water. Karababa (2006) verified a $40.16 \%$ decrease in the superficial area of popcorn kernels with reduction in the moisture content from 17.12 to 8.95 (\% w.b.). Goneli et al. (2008) observed a decrease around 23 $\mathrm{mm}^{2}$ with the reduction in the moisture content from 0.55 to 0.09 (decimal d.b.) in seeds of castor bean, which is a plant belonging to the same family of the physic nut.

The superficial area of the jatropha beans ranged between 479.6 and $419.1 \mathrm{~mm}^{2}$ (Figure 6). These values are lower than those obtained by Santos et al. (2009), who reported jatropha beans with moisture content of $8.73 \pm$ 0.099 (\% w.b.) with a superficial area of $538.46 \mathrm{~mm}^{2}$. Garnayak et al. (2008) obtained results ranging from 476.78 to $521.99 \mathrm{~mm}^{2}$ at moisture content range from 4.75 to $19.57 \%$ (w.b.) for jatropha beans. The divergences in the superficial area might be related to both the variety of the

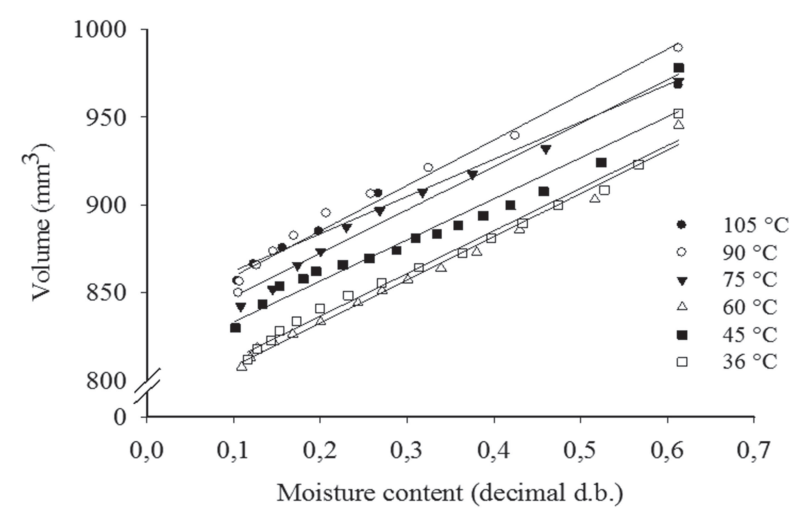

Figure 5. Volume of the jatropha beans subjected to six drying temperatures.

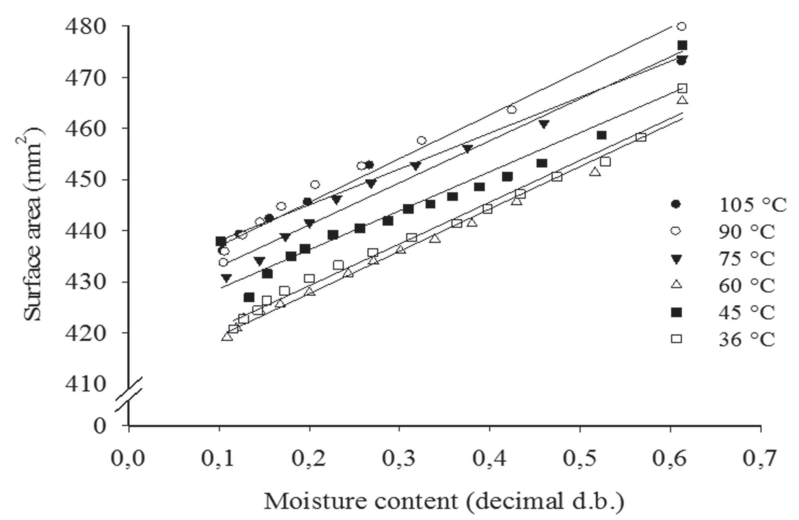

Figure 6. Surface area of the jatropha beans subjected to six drying temperatures.

Rev. Ceres, Viçosa, v. 60, n.6, p. 820-825, nov/dez, 2013 
beans and the management adopted during the periods before and/or after harvest.

The projected area $\left(\mathrm{mm}^{2}\right)$ of the jatropha beans decreased with the reduction in the moisture content, presenting the values $12.07 ; 15.86 ; 15.54 ; 15.50 ; 16.75$; and $15.77 \mathrm{~mm}^{2}$ relative to the initial projected area, for temperatures of $105,90,75,60,45$, and $36^{\circ} \mathrm{C}$, respectively (Figure 7). It was observed that the drying at $105{ }^{\circ} \mathrm{C}$ promoted lower reduction in the initial projected area; such behavior is similar to that observed for the variable volume. When evaluating the projected area of castor-oil fruits submitted to drying at $40{ }^{\circ} \mathrm{C}$ temperature, Goneli et al. (2008) observed an approximate variation from 391 to 259 $\mathrm{mm}^{2}$, with the moisture content reduction from 2.5 to 0.13 (decimal d.b.). The reduction in the projected area as a function of the reduction in the moisture content has also been observed for other grains (Aydin, 2007; Dursun et al., 2007; Yalçin et al., 2007).

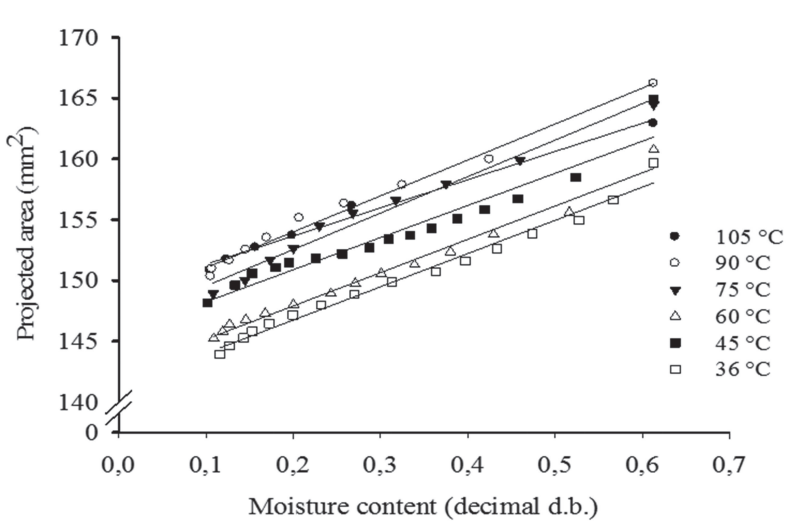

Figure 7. Projected area of the jatropha beans subjected to six drying temperatures.
The reduction in the moisture content increased the surface/volume ratio, under the six conditions analyzed (Figure 8). According to Farinha (2008), if only physical factors were involved, the water loss rate was proportional to the surface/volume ratio and supposing the product shape to be constant, the volume/surface ratio increased with the reduction in the size.

The models presented high significance level by the F-test, as well as high determination coefficient $\left(\mathrm{R}^{2}\right)$, superior to $93 \%$, except for the surface/volume ratio at $45^{\circ} \mathrm{C}$ (Table 1). Thus, the models satisfactorily described the behavior of the variables analyzed as a function of the moisture content. The adjustment of the linear models to the same physical properties have also been reported in other studies (Baryeh, 2002; Nimkar et al., 2005; Karababa, 2006; Garnayak et al., 2008; Pradhan et al., 2009). However, the models were not significant for both sphericity and roundness of the jatropha beans along drying.

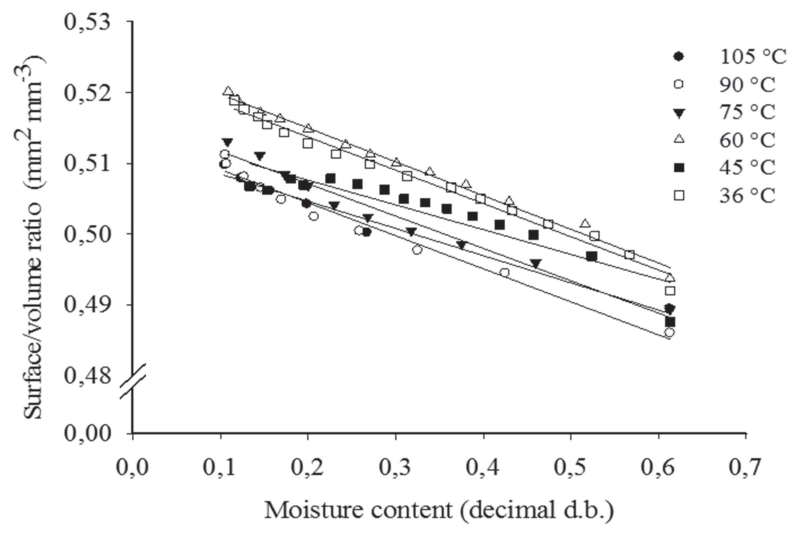

Figure 8. Surface/volume ratio of the jatropha beans subjected to six drying temperatures.

Table 1. Equations adjusted to values of the projected area $\left(\mathrm{Ap}, \mathrm{mm}^{2}\right)$, superficial area $\left(\mathrm{S}, \mathrm{mm}^{2}\right)$, volume $\left(\mathrm{V}_{\mathrm{g}}, \mathrm{mm}^{3}\right)$ and the volume/ surface $\left(\mathrm{SV}, \mathrm{mm}^{2} \mathrm{~mm}^{3}\right)$ ratio of the jatropha beans as a function of the moisture content (MC, decimal d.b.) ${ }^{{ }^{2}}$

\begin{tabular}{|c|c|c|c|c|c|}
\hline \multicolumn{3}{|c|}{ Projected area } & \multicolumn{3}{|c|}{ Surface area } \\
\hline $\mathbf{T}\left({ }^{\circ} \mathbf{C}\right)$ & Model & $\mathbf{R}^{2}(\%)$ & $\mathbf{T}\left({ }^{\circ} \mathbf{C}\right)$ & Model & $\mathbf{R}^{2}(\%)$ \\
\hline 105 & $A_{p}=23.19 M C+149.0$ & $98.6^{* *}$ & 105 & $\mathrm{~S}=70.37 \mathrm{MC}+430.9$ & $98.2^{* *}$ \\
\hline 90 & $\mathrm{~A}_{\mathrm{p}}^{\mathrm{p}}=29.56 \mathrm{MC}+148.0$ & $98.7^{* *}$ & 90 & $\mathrm{~S}=85.71 \mathrm{MC}+428.3$ & $97.9^{* *}$ \\
\hline 75 & $A_{p}=30.00 M C+146.5$ & $97.9^{* *}$ & 75 & $\mathrm{~S}=82.24 \mathrm{MC}+424.6$ & $97.6^{* *}$ \\
\hline 60 & $A_{p}=27.39 \mathrm{MC}+142.4$ & $98.2^{* *}$ & 60 & $\mathrm{~S}=82.97 \mathrm{MC}+411.0$ & $98.8^{* *}$ \\
\hline 45 & $A_{p}=26.43 \mathrm{MC}+145.6$ & $93.0^{* *}$ & 45 & $\mathrm{~S}=76.43 \mathrm{MC}+420.9$ & $90.1^{* *}$ \\
\hline 36 & $A_{p}=27.33 \mathrm{MC}+141.2$ & $98.3^{* *}$ & 36 & $\mathrm{~S}=81.84 \mathrm{MC}+412.8$ & $98.4^{* *}$ \\
\hline \multicolumn{3}{|c|}{ Volume } & \multicolumn{3}{|c|}{ Volume/surface ratio } \\
\hline $\mathbf{T}\left({ }^{\circ} \mathbf{C}\right)$ & Model & $\mathbf{R}^{2}(\%)$ & $\mathbf{T}\left({ }^{\circ} \mathbf{C}\right)$ & Model & $\mathbf{R}^{2}(\%)$ \\
\hline 105 & $\mathrm{~V}_{\mathrm{g}}=212.2 \mathrm{MC}+841.2$ & $98.4^{* *}$ & 105 & $\mathrm{SV}=-0.038 \mathrm{MC}+0.512$ & $97.7^{* *}$ \\
\hline 90 & $\mathrm{~V}_{\mathrm{g}}^{\circ}=258.6 \mathrm{MC}+833.5$ & $98.1^{* *}$ & 90 & $\mathrm{SV}=-0.046 \mathrm{MC}+0.513$ & $97.3^{* *}$ \\
\hline 75 & $\mathrm{~V}_{\mathrm{g}}^{\mathrm{g}}=246.7 \mathrm{MC}+823.1$ & $97.8^{* *}$ & 75 & $\mathrm{SV}=-0.045 \mathrm{MC}+0.516$ & $96.9^{* *}$ \\
\hline 60 & $\mathrm{~V}_{\mathrm{g}}^{\mathrm{g}}=246.1 \mathrm{MC}+783.5$ & $98.7^{* *}$ & 60 & $\mathrm{SV}=-0.047 \mathrm{MC}+0.524$ & $99.0^{* *}$ \\
\hline 45 & $\mathrm{~V}_{\mathrm{g}}^{\mathrm{g}}=233.9 \mathrm{MC}+809.9$ & $94.0^{* *}$ & 45 & $\mathrm{SV}=-0.035 \mathrm{MC}+0.514$ & $82.2^{* *}$ \\
\hline 36 & $\mathrm{~V}_{\mathrm{g}}^{\mathrm{g}}=242.6 \mathrm{MC}+788.2$ & $98.3^{* *}$ & 36 & $\mathrm{SV}=-0.047 \mathrm{MC}+0.523$ & $98.6^{* *}$ \\
\hline
\end{tabular}

**Significant at $1 \%$ probability level, by $\mathrm{F}$ test.

Rev. Ceres, Viçosa, v. 60, n.6, p. 820-825, nov/dez, 2013 


\section{CONCLUSIONS}

The reduction of moisture content promotes a small change in roundness and sphericity of jatropha beans. The increase or decrease changes are related to the drying temperature.

The volume, projected area and surface area linearly reduce with the drying process regardless of the temperature used.

The reduction of moisture content linearly increases the surface / volume ratio of jatropha beans in all drying conditions.

\section{ACKNOWLEDGEMENTS}

The authors acknowledge the Conselho Nacional de Desenvolvimento Científico e Tecnológico (CNPq), Coordenação de Aperfeiçoamento de Pessoal de Nível Superior (CAPES) and the Instituto Federal de Educação, Ciência e Tecnologia Goiano (IFGoiano - Campus Rio Verde) for the financial support on this study.

\section{REFERENCES}

Aydin C (2007) Some engineering properties of peanut and kernel. Journal of Food Engineering, 79:810-816.

Baryeh EA (2002) Physical properties of millet. Journal of Food Engineering, 51:39-46.

Brasil (2009) Ministério da Agricultura Pecuária e Abastecimento. Secretaria de Defesa Agropecuária. Regras para análise de sementes. Brasília, RAS. 395p.

Corrêa PC, Ribeiro MD, Resende O \& Botelho FM (2006) Determinação e modelagem das propriedades físicas e da contração volumétrica do trigo, durante a secagem. Revista Brasileira de Engenharia Agrícola e Ambiental, 10:665-670.

Dursun I, Tuðrul KM \& Dursun E (2007) Some physical properties of sugarbeet seed. Journal of Stored Products Research, 43:149155 .

Farinha LRL (2008) Características físicas na perda da matéria fresca e evolução das propriedades reológicas e cor da cenoura cv. Brasília no armazenamento. Dissertação de Mestrado. Universidade Federal de Viçosa, Viçosa. 111p.

Garnayak DK, Pradhan RC, Naik SN \& Bhatnagar N (2008) Moisture-dependent physical properties of Jatropha seed (Jatropha curcas L.). Industrial crops and products, 27:123129.

Goneli ALD, Corrêa PC, Botelho FM, Oliveira GHH \& Santos E S (2008) Propriedades físicas dos frutos de mamona durante a secagem. Revista Brasileira de Armazenamento, 33:148-155.

Karababa E (2006) Physical properties of popcorn kernels. Journal of Food Engineering, 72:100-107.

Lahsasni S, Kouhila M, Mahrouz M \& Jaouhari JT (2004) Drying kinetcs of prickly pear fruit (Opuntia ficus indica). Journal of Food Engineering, 2:173-179.

Mohapatra D \& Rao PS (2005) A thin layer drying model of parboiled wheat. Journal of Food Engineering, 66:513-518.

Mohsenin NN (1986) Physical properties of plant and animal materials. New York, Gordon \& Breach Publishers. 841p.
Nimkar PM, Mandwe DS \& Dudhe RM (2005) Physical Properties of Moth Gram. Biosystems Engineering, 91:183-189.

Nóbrega MBM, Andrade FP, Santos JW \& Leite EJ (2001) Germoplasma. In: Azevedo DMP de \& Lima EF (Eds.) O agronegócio da mamona no Brasil. Brasília, Embrapa Serviço de Comunicação Tecnológica. 350p.

Pradhan RC, Naik SN, Bhatnagar N \& Vijay VK (2009) Moisturedependent physical properties of jatropha fruit. Industrial Crops and Products, 29:341-347.

Resende O, Corrêa PC, Goneli ALD \& Cecon PR (2005) Forma, tamanho e contração volumétrica do feijão (Phaseolus vulgaris L.) durante a secagem. Revista Brasileira de Produtos Agroindustriais, 7:15-24.

Resende O, Corrêa PC, Goneli ALD, Botelho FM \& Rodrigues S (2008) Modelagem matemática do processo de secagem de duas variedades de feijão (Phaseolus vulgaris L.). Revista Brasileira de Produtos Agroindustriais, 10:17-26.

Resende O, Rodrigues S, Siqueira VC \& Arcanjo RV (2010) Cinética da secagem de clones de café (Coffea canephora Pierre) em terreiro de chão batido. Acta Amazonica, 40:247-255.

Santos SB, Martins MA, Carvalho FM \& Carneiro ACO (2009) Determinação de algumas propriedades físicas dos grãos de pinhão manso (Jatropha curcas L.) In: Di Leo N, Montico S \& Nardón G (Eds.) Avances en Ingeniería Rural: 2007 - 2009. Rosario, UNR. p.1067-1072.

Silva JS (2008) Secagem e Armazenagem de Produtos Agrícolas. Viçosa, Aprenda Fácil. 559p.

Siqueira VC (2011) Propriedades físicas e secagem de grãos de pinhão-manso (Jatropha curcas L.). Dissertação de Mestrado. Instituto Federal de Educação, Ciência e Tecnologia Goiano, Rio Verde. $85 \mathrm{p}$.

Siqueira VC, Resende O, Chaves TH \& Soares FAL (2012) Forma e tamanho dos frutos de pinhão-manso durante a secagem em cinco condições de ar. Revista Brasileira de Engenharia Agrícola e Ambiental, 16:864-870.

Sirisomboon P, Kitchaiya P, Pholpho T \& Mahuttanyavanitch W (2007) Physical and mechanical properties of Jatropha curcas L. fruits, nuts and kernels. Biosystems Engineering, 97:201207.

Sirisomboon P \& Kitchaiya P (2009) Physical properties of Jatropha curcas L. kernels after heat treatments. Biosystems Engineering, 102:244-250.

Tunde-Akinntunde TY \& Akintunde BO (2004) Some physical properties of sesame seed. Biosystems Engineering, 88:127129.

Yalçin Ý, Özarslan C \& Akbap T (2007) Physical properties of pea (Pisum sativum) seed. Journal of Food Engineering, 79:731735 . 